\title{
Synthesis and Characterization of NaA Zeolite Using Natural Kaolinite Clays from Nigeria by Low Temperature Hydrothermal Method
}

\author{
Ifedayo Joshua Akinruli ${ }^{1}$, Seun Samuel Owoeye ${ }^{2}$, Segun Michael Abegunde ${ }^{3 *}$, Ayodeji E. Onipede ${ }^{4}$, \\ Ukoba Kingsley ${ }^{5}$ \\ ${ }^{1,2}$ Department of Glass and Ceramics, Federal Polytechnic, Ado-Ekiti, Nigeria \\ ${ }^{3,4}$ Department of Science Technology, Federal Polytechnic, Ado-Ekiti, Nigeria \\ ${ }^{5}$ University of Kwazulu Natal, Durban, South Africa
}

\begin{abstract}
Zeolites $\mathrm{NaA}$ is one of the most valuable synthetic zeolites widely used as ion-exchange material, catalysts, and adsorbents in industry. There is therefore need to adopt a more energy-efficient route for its synthesis from low-cost and sustainable raw materials. In this present work, zeolites Na-A was synthesized from natural kaolinite clays obtained from three selected regions (Ikere, Okpella and Kankara) in Nigeria. The asreceived kaolinite clays ( $\mathrm{IK}_{\text {clay }}, \mathrm{OK}_{\text {clay }}$ and $\mathrm{KA}_{\text {clay }}$ ) were initially beneficiated thoroughly to obtain pure powders $(<75 \mu \mathrm{m})$. The processed kaolinite clay powders were then subjected to heating in a muffle furnace at $850^{\circ} \mathrm{C}$ for $3 \mathrm{~h}$ at a heating rate of $10^{\circ} \mathrm{C} / \mathrm{min}$ to convert the kaolinite clays to their respective metakaolins. The obtained metakaolins were then reacted with $\mathrm{NaOH}$ solutions at varying concentrations of 3.0 and $4.0 \mathrm{M}$ respectively using a low temperature hydrothermal transformation to obtained Zeolites Na-A powders. The obtained zeolites were then analyzed by scanning electron microscopy (FESEM), energy dispersive spectroscopy (EDS) and Fourier-transform infrared spectroscopy (FT-IR). The results showed that zeolite $\mathrm{NaA}$ is produced with mixture of hydroxysodalite (HS) while the EDS revealed the presence of $\mathrm{Si}, \mathrm{Al}, \mathrm{O}$ and $\mathrm{Na}$ indicating chemical constituents of typical zeolite $\mathrm{NaA}$. All the tested kaolinite clays are therefore suitable for preparation of zeolite $\mathrm{NaA}$ as cheaper source of silica and aluminum.
\end{abstract}

Keywords: Na-A zeolites, kaolinite clays, hydroxysodalite, hydrothermal transformation.

\section{Introduction}

Zeolites are one of a large group of microporous, crystalline and hydrous aluminosilicates of alkali and alkaline earth metals with a unique $3 \mathrm{D}$ structural framework comprising of $\left[\mathrm{SiO}_{4}\right]^{4-}$ and $\left[\mathrm{AlO}_{4}\right]^{5-}$ tetrahedral units connected through shared oxygen [1], [2]. Zeolites find relevance in several industrial applications such as catalytic cracking of petroleum, treatment of wastewaters, ion exchangers, drying of gases and liquids, purification of industrial effluents and emissions etc. thereby making its synthesis in forms suitable for industrial applications of great relevance [1]-[4]. At present, there are about 50 identified naturally occurring zeolites and more than 150 known synthetic zeolites [5], [6]. In previous times, only natural zeolites were used, but more recently synthetic zeolites are often preferred commercially due to the purity of crystalline products and particle sizes uniformity thereby resulting to tailor-made zeolites which are extremely replicable [2], [7]. Out of these lots, Zeolite NaA finds a major industrial prominence due to its excellent molecular sieving, ion exchange and adsorption attributes [1]. The preparation of synthetic zeolites using chemically pure sources of silica and alumina as starting materials is known to be quite expensive; as a result, cheaper sources of silica and alumina such as clay minerals, industrial slag, incineration ashes, municipal solid wastes etc. are being continuously investigated as starting materials with promising results [8], [9]. The crucial factors influencing the synthesis of zeolite-type are the $\mathrm{Si} / \mathrm{Al}$ ratio, temperature, hydrodynamics, reaction time and alkalinity [2]. With $\mathrm{Si} / \mathrm{Al}$ molar ratio almost equal to 1, kaolinite clay is a suitable raw material for preparation of zeolite $\mathrm{NaA}$ and having the advantage of being relatively cheaper, highly abundant and readily available [10]. The utilization of kaolin as a precursor of silica and alumina in the preparation of zeolite NaA was started in the 1970s [2], [11] by the reaction of dehydroxylated kaolin (metakaolin) with $\mathrm{NaOH}$ solution and since then, several attempts are still ongoing with regard to the use of kaolinite clay and metakaolin (dehydroxylated kaolin) from various countries of the world for synthesis of zeolite Type A, NaA, Y, X, 4A, P, hydroxysodalite, faujasite etc. giving rise to an extensive literature [7], [12]-[18]. However, no attempt has been previously made to synthesize zeolite $\mathrm{NaA}$ using natural kaolinite clays from Nigeria.

In this work, zeolite $\mathrm{NaA}$ was synthesized by conventional hydrothermal method using kaolinite clays obtained from three prominent deposits (Ikere, Opkella and Kankara) in Nigeria and sodium hydroxide solutions at varying concentration. The synthesized zeolite products were analyzed using scanning electron microscopy with attached energy dispersive spectroscopy (SEM/EDS), Fourier transform infrared spectroscopy (FT-IR) and X-ray diffraction (XRD). 


\section{Materials and Methods}

\section{A. Material preparation}

The starting materials used in this present study are kaolinite clays and sodium hydroxide pellets. The kaolinite clays used in this present investigation were obtained from three different zones in Nigeria, namely: Ikere Ekiti $\left(7.4991^{\circ} \mathrm{N}, 5.2319^{\circ} \mathrm{E}\right)$ in Ekiti State, Okpella $\left(7.272^{\circ} \mathrm{N}, 6.3465^{\circ} \mathrm{E}\right)$ in Edo State and Kankara $\left(11.9313^{\circ} \mathrm{N}, 7.4138^{\circ} \mathrm{E}\right)$ in Katsina State while sodium hydroxide pellets (purity 98\%) was obtained from a reliable chemical vendor.

The kaolinite clays which were obtained in their as-received state were labeled $\mathrm{IK}_{\text {clay }}$ (Ikere clay), $\mathrm{OK}_{\text {clay }}$ (Okpella clay) and $\mathrm{KA}_{\text {clay }}$ (Kankara clay) respectively. These clays were taken through beneficiation route following standard procedures in order to obtain highly pure clay free from organic matter and other attached impurities. The pure clays were further milled and then sieved respectively through a $75 \mu \mathrm{m}$ sieve. By colour identification after processing, Okpella kaolinite is the most whitish clay among the three different processed clays. The kaolinite clays were then subjected to heating (calcination) inside a muffle furnace at $850^{\circ} \mathrm{C}$ for $3 \mathrm{~h}$ in order to convert the kaolinite clays to their respective metakaolins which are used in the preparation of zeolite. This is done to obtain a more reactive phase (amorphous metakaolin) as previous work has shown that raw kaolin is unstable under high alkaline conditions resulting into formation of different zeolitic materials [1]. The processed kaolinite clays are shown in figures 1 (a-c) respectively.

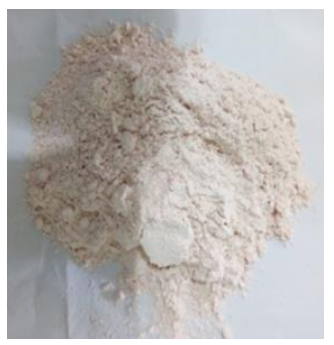

(a)

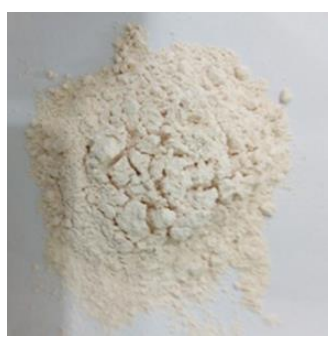

(b)

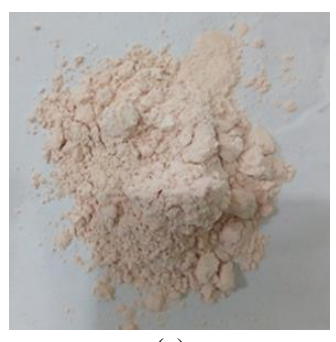

(c)

Fig. 1. Processed kaolinite clays (a) $\mathrm{IK}_{\text {clay }}$ (b) $\mathrm{OK}_{\text {clay }}$ (c) $\mathrm{KA}_{\text {clay }}$

\section{B. Synthesis of zeolite NaA (Hydrothermal method)}

In this present investigation, the obtained metakaolins from $\mathrm{IK}_{\text {clay }}$ (Ikere clay), $\mathrm{OK}_{\text {clay }}$ (Okpella clay) and $\mathrm{KA}_{\text {clay }}$ (Kankara clay) respectively were not dealuminated as done by some previous studies in order to further reduce cost of preparation. However, the synthesis of zeolite in this work followed the adopted method by Mousa and Buhl [1].

Metakaolins from each kaolinite clay sample were separately mixed with sodium hydroxide $(\mathrm{NaOH})$ solutions of varying concentrations of 3.0 and $4.0 \mathrm{M}$ respectively. The samples were initially stirred gently for about $10 \mathrm{~min}$ at room temperature for proper homogenization. The solid/liquid ratio of metakaolins to alkaline solution was $1.0 \mathrm{~g} / 25 \mathrm{ml}$. The obtained gels from the reacted mixtures were then left to cure for 7 days under room temperature. After the completion of curing, the gels obtained from respective metakaolin were then heated to hydrothermally crystallize at $100^{\circ} \mathrm{C}$ for $24 \mathrm{~h}$ following the adopted method of Adeoye et al. [19]. The synthesized zeolites were then washed with distilled water three times followed by drying at $80^{\circ} \mathrm{C}$ for $24 \mathrm{~h}$.

\section{Characterization of the raw materials and as-synthesized zeolite NaA}

Characterization was carried out on the processed kaolinite clays and the synthesized zeolite NaA respectively in order to study their properties using standard procedures. The chemical composition was examined using high performance Energy Dispersive Spectrum (EDS) to quantify the concentrations of the elements present. Phase identifications were determined by X-ray diffractometer using BRUKER AXS with D8 Advanced diffractometer $\mathrm{Cu} \mathrm{K} \alpha$ radiation XRD in the range of 2 tetha angle from 5 to 70 scanning range. The morphology features were examined by high performance scanning electron microscope (FESEM, Hitachi S-2460 N) in order to assess their microstructure characteristics. Identification of molecular bonding of the kaolinite clays were evaluated using Fouriertransform infrared spectroscopy (Shimadzu FTIR - 4200).

\section{Results and Discussions}

\section{A. Characterization of the starting materials}

Figure 2 (a) - (c) showed the results of the morphology and chemical composition of the three clays (IK, OK and KA respectively) by SEM/EDS while Figure 3 (a) - (c) revealed the mineralogical constituents of the clays by X-ray diffraction analysis. Figure 4 (a) - (b) displayed the functional bonding existing in the kaolinite clays.

In Figure 2(a) - (c), it is observed that three kaolinite clays displayed a similar somewhat platy morphology with hexagonal outlines characteristics of kaolinite, though with few agglomerations. This feature has also been reported by previous works $[1,20]$. However, the chemical composition by the EDS showed the presence of predominant peaks of $\mathrm{Si}, \mathrm{Al}$ and $\mathrm{O}$ indicating typical elements of kaolinite clays. In Figure 3 (a) (c) shown by the XRD pattern, it is observed that kaolinite is the predominant mineral phase in all the three clays which can be recognized by their distinctive reflections at $12.34^{\circ}$ and 
$24.64^{\circ}$ of 2 tetha as stated by Zhao et al. (2004). However, the presence of quartz is also confirmed by the XRD patterns for all the three clays, while minor impurity like muscovite is observed for $\mathrm{KA}_{\text {clay }}$ sample (Fig. 3c). In Figure 4 (a) - (b) indicated by the FT-IR spectra, it is observed that all the three clays exhibited somewhat similar pattern and bonding values. The peaks observed at $3687.9,3618.46,3647.39,1114.86,1028.06$, 912.33 and $750.31 \mathrm{~cm}^{-1}$ are characteristics of kaolinite [21]. The absorption bands observed between $3566.38-3687.90 \mathrm{~cm}^{-1}$ might be attributed to $\mathrm{Al}-\mathrm{O}-\mathrm{H}$ stretching while peaks at 1028.06 and $1114.86 \mathrm{~cm}^{-1}$ are attributed to $\mathrm{Si}-\mathrm{O}$ stretching [22]. Also the bands appearing at 750.31, 910.4 and $912.33 \mathrm{~cm}^{-}$ 1 respectively can be attributed to $-\mathrm{OH}$ deformation [23]. However, the bands observed at 530.42 and $534.28 \mathrm{~cm}^{-1}$ respectively might be attributed to $\mathrm{Si}-\mathrm{O}-\mathrm{Al}$ stretching [23]. The bands appearing at $1417.68-1489.05 \mathrm{~cm}^{-1}$ might indicate the presence of carbonate bearing minerals which is confirmed by their EDS spectra [21].

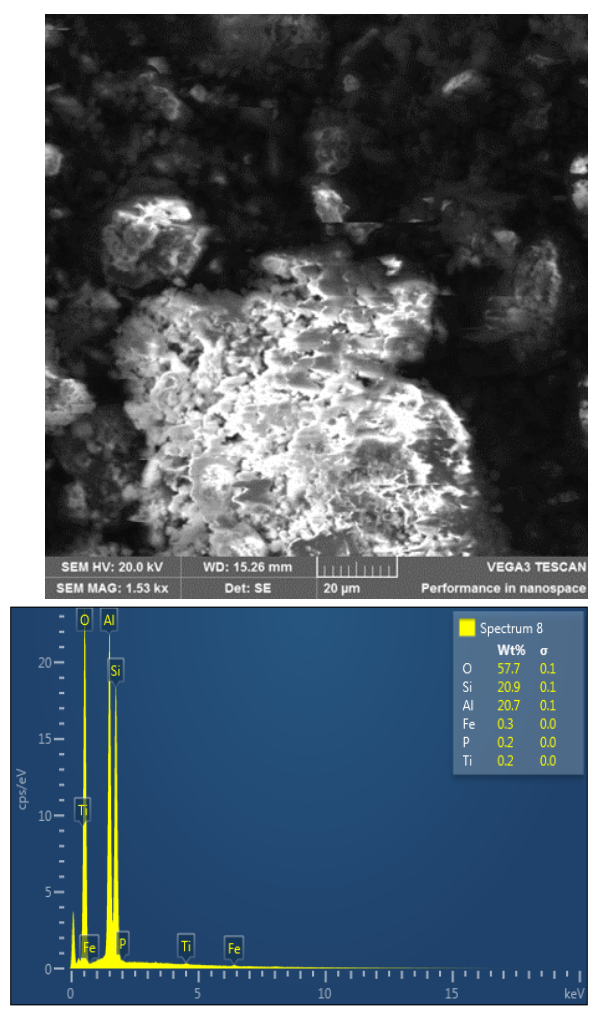

(a)

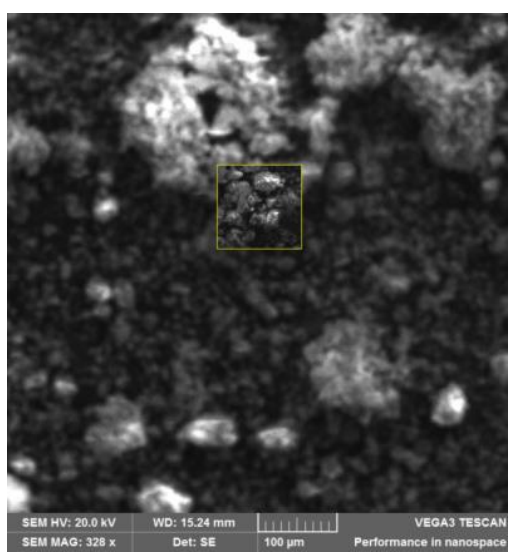

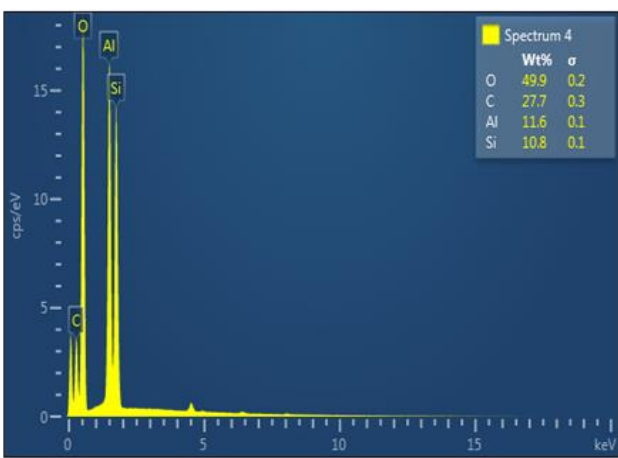

(b)

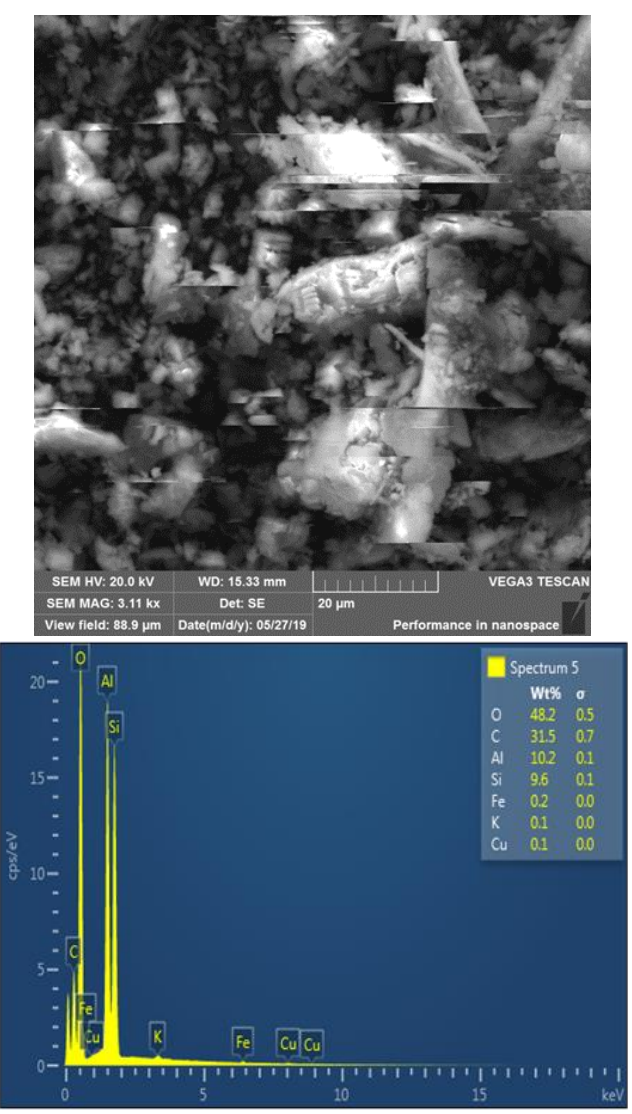

(c)

Fig. 2. Morphology and chemical composition of (a) Ikere clay (b) Okpella clay (c) Kankara clay

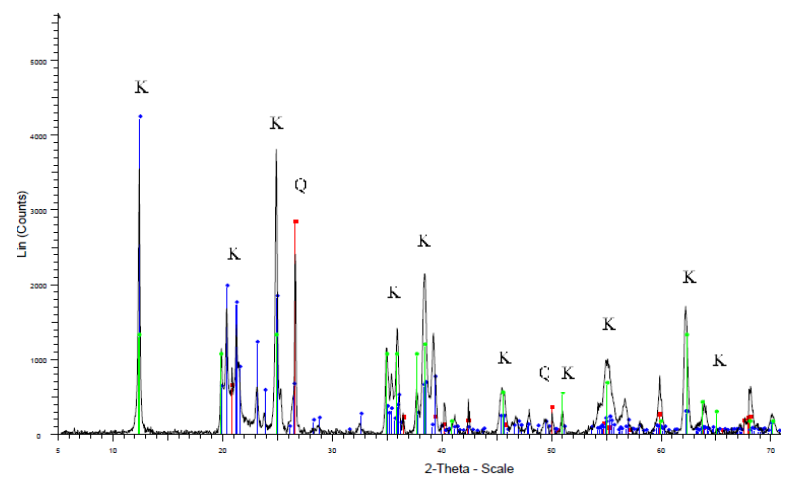

(a) 


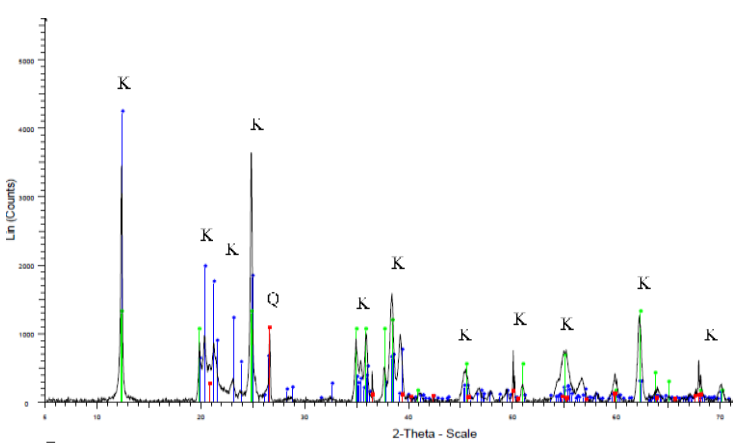

(b)

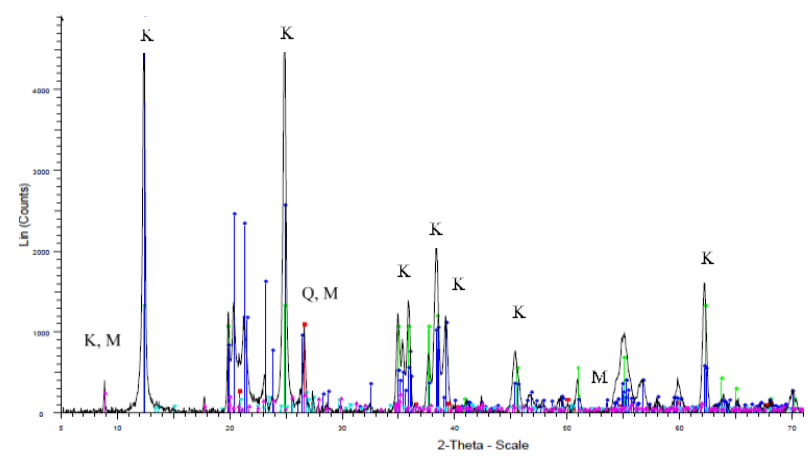

(c)

K - Kaolinite (blue, green), Q - Quartz (red), M - Muscovite (purple) Fig. 3. X-ray diffraction analysis of (a) Ikere clay (b) Okpella clay (c) Kankara clay

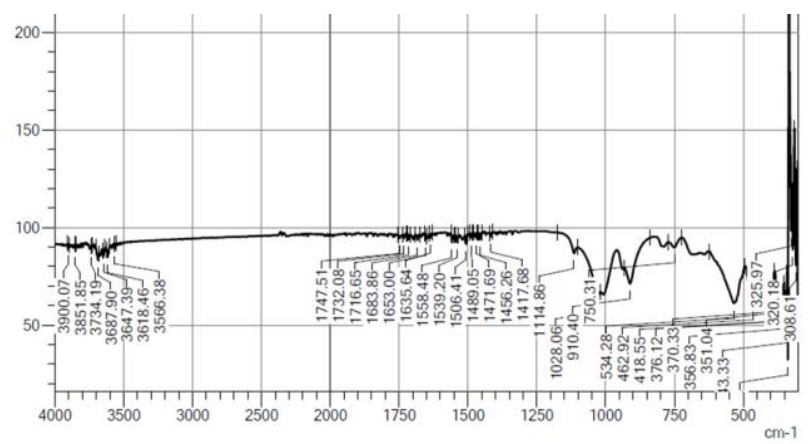

(a)

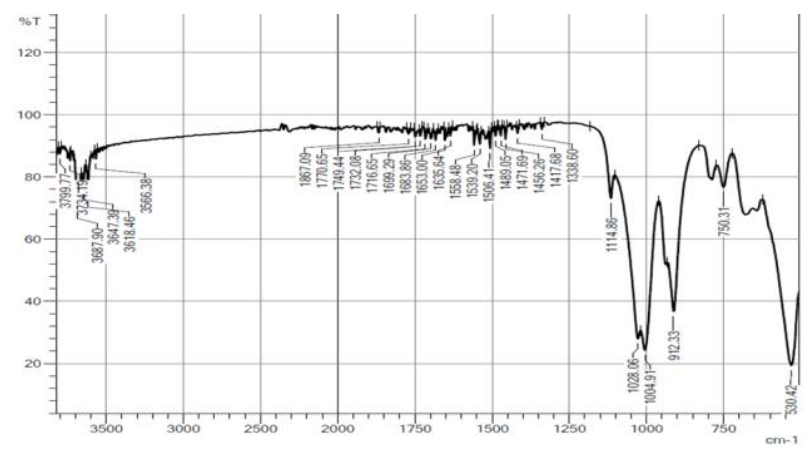

(b)

Fig. 4. Representative FT-IR spectra of (a) Ikere clay (b) Okpella clay

\section{B. Characterization of the synthesized NaA Zeolite}

\section{1) Morphology characteristics}

Figures $5(\mathrm{a}-\mathrm{c})$ and Figures $6(\mathrm{a}-\mathrm{c})$ represent the morphologies of the as-synthesized zeolite products at $\mathrm{NaOH}$ concentration of 3.0 and $4.0 \mathrm{M}$ respectively. The morphologies showed a pronounced change from the morphologies of the stating materials (kaolinite clays) used. It is observed that the morphologies of the synthesized zeolite $\mathrm{NaA}$ at both $\mathrm{NaOH}$ concentrations $(3.0$ and $4.0 \mathrm{M}$ ) is somewhat similar. Zeolite $\mathrm{NaA}$ can be identified in its characteristics cubic morphology, however, the morphology obtained in this work reveals irregular but somewhat spherical aggregates of Zeolite $\mathrm{NaA}$ crystals. The cubic crystals probably developed before emergence of hydroxysodalite (HS) growing at the surface of zeolite NaA. The occurrence of hydroxysodalite alongside zeolite $\mathrm{NaA}$ has been attributed to be dependent on the concentration of $\mathrm{NaOH}$ solution [1]. Hydroxysodalite occurs at high concentration of $\mathrm{NaOH}$ solution as observed in this work. At $4.0 \mathrm{M} \mathrm{NaOH}$, it is observed that lephispheric morphologies similar to hydroxysodalite grew out at the surface of the cubic crystals of zeolite $\mathrm{NaA}$, showing interpenetrating twining (Fig. $6 \mathrm{a}, \mathrm{b}, \mathrm{c})$. This has also been reported by Mousa and Buhl [1] and also similar to morphology obtained by Zahra and Habibollah [24]. Usually, it is proper to observe the following phenomenon between phases of hydroxysodalite and zeolite $\mathrm{NaA}$ : crystals of hydroxysodalite growing on the surface of cubic crystals of zeolite NaA, and aggregates of cotton ball-like spheroidal structure of hydroxysodalite occurring with cubic crystals of zeolite $\mathrm{NaA}$ [1]. It is also observed that when concentration of $\mathrm{NaOH}$ is increased from 3.0 to $4.0 \mathrm{M}$, the lephispheric morphology indicated by the spheroidal cottonball like morphologies increased which might be due to increase in sodium (sodalite) as confirmed by the EDS spectra. The results of the chemical composition shown by the EDS indicates the peaks of $\mathrm{Si}, \mathrm{O}, \mathrm{Al}$ and $\mathrm{Na}$ as major elements thereby confirmed that the synthesized products are zeolite $\mathrm{NaA}$. It can also be observed that the sodium $(\mathrm{Na})$ content increases with increase in $\mathrm{NaOH}$ concentration used which is actually expected thus resulting into growing of hydroxysodalite phase in the Zeolite NaA matrix. However, zeolite NaA synthesized from Okpella kaolinite clay ( $\left.\mathrm{OK}_{\text {clay }}\right)$ exhibited less hydroxysodalite phase.

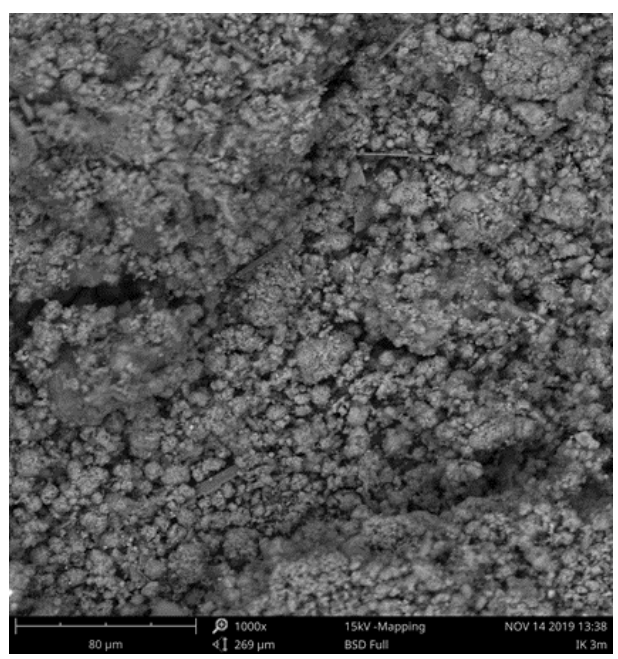




\begin{tabular}{|l|l|l|l|}
\hline Element Symbol & Element Name & Atomic Conc. & Weight Conc. \\
\hline $\mathrm{O}$ & Oxygen & 37.62 & 28.45 \\
\hline $\mathrm{Si}$ & Silicon & 20.78 & 27.59 \\
\hline $\mathrm{Al}$ & Aluminum & 15.14 & 19.31 \\
\hline $\mathrm{Na}$ & Sodium & 10.92 & 11.87 \\
\hline $\mathrm{Fe}$ & Iron & 0.34 & 0.90 \\
\hline $\mathrm{K}$ & Potassium & 0.29 & 0.53 \\
\hline $\mathrm{P}$ & Phosphorus & 0.28 & 0.41 \\
\hline $\mathrm{Cl}$ & Chlorine & 0.13 & 0.22 \\
\hline
\end{tabular}

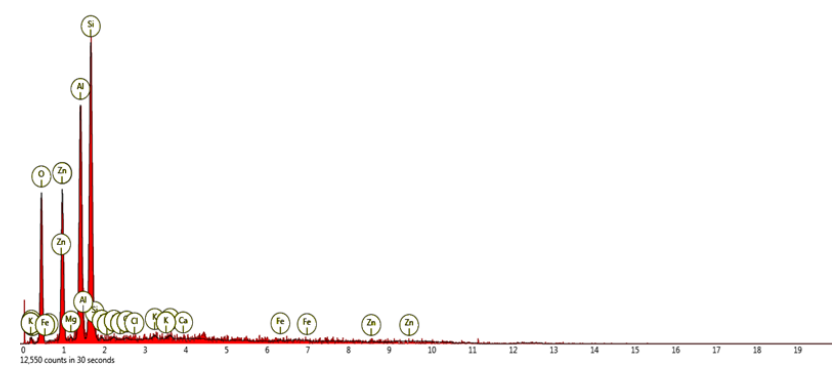

(a)

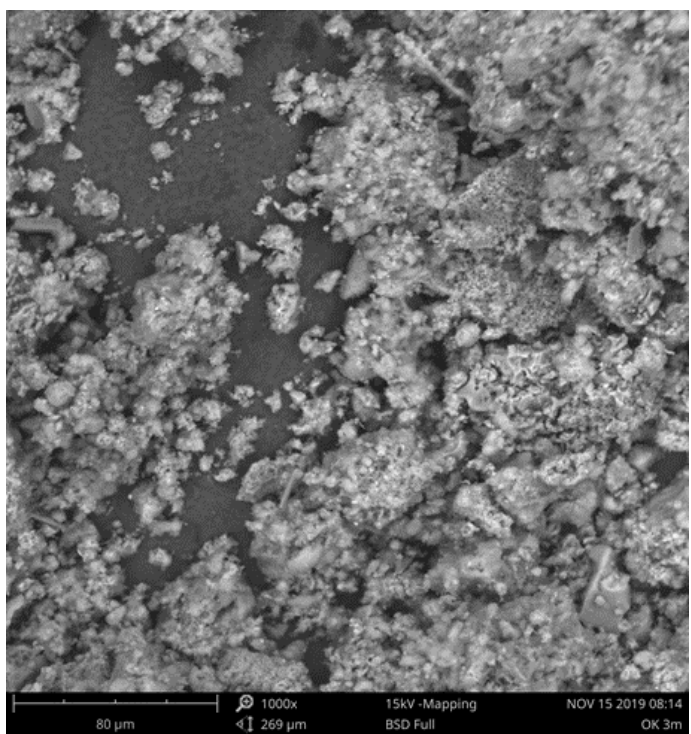

\begin{tabular}{|l|l|r|r|}
\hline Element Symbol & Element Name & Atomic Conc. & Weight Conc. \\
\hline $\mathrm{Si}$ & Silicon & 34.68 & 38.42 \\
\hline $\mathrm{Al}$ & Aluminum & 22.19 & 23.62 \\
\hline $\mathrm{O}$ & Oxygen & 24.34 & 15.36 \\
\hline $\mathrm{Na}$ & Sodium & 11.56 & 10.48 \\
\hline $\mathrm{Fe}$ & Iron & 0.81 & 1.79 \\
\hline $\mathrm{K}$ & Potassium & 0.87 & 1.34 \\
\hline $\mathrm{Cl}$ & Chlorine & 0.64 & 0.89 \\
\hline $\mathrm{P}$ & Phosphorus & 0.67 & 0.81 \\
\hline
\end{tabular}

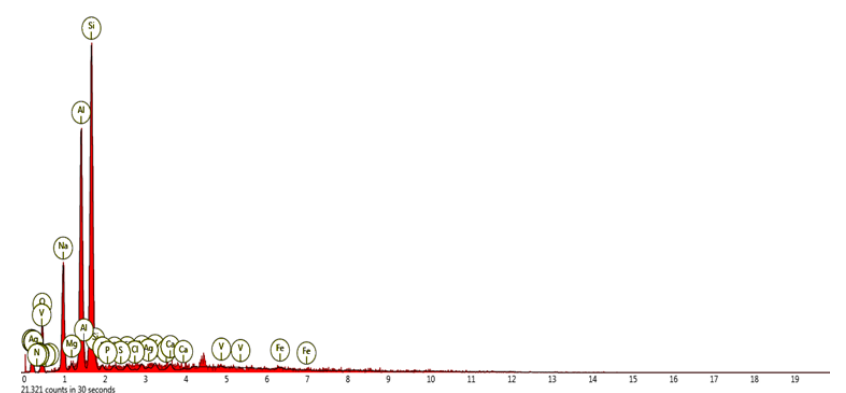

(b)

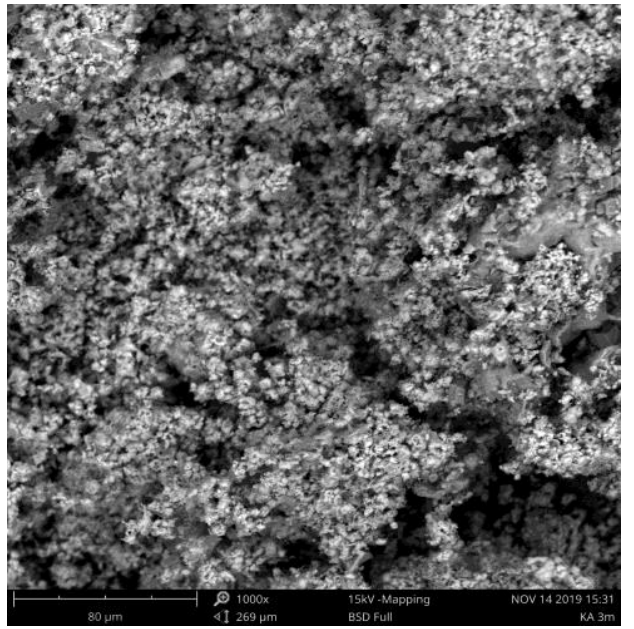

\begin{tabular}{|l|l|r|r|}
\hline Element Symbol & Element Name & Atomic Conc. & Weight Conc. \\
\hline $\mathrm{Si}$ & Silicon & 27.20 & 32.60 \\
\hline $\mathrm{Al}$ & Aluminum & 18.33 & 21.10 \\
\hline $\mathrm{O}$ & Oxygen & 22.84 & 15.59 \\
\hline $\mathrm{Na}$ & Sodium & 12.41 & 12.17 \\
\hline $\mathrm{K}$ & Potassium & 0.60 & 0.99 \\
\hline $\mathrm{P}$ & Phosphorus & 0.46 & 0.61 \\
\hline $\mathrm{Cl}$ & Chlorine & 0.39 & 0.58 \\
\hline $\mathrm{Fe}$ & Iron & 0.18 & 0.43 \\
\hline
\end{tabular}

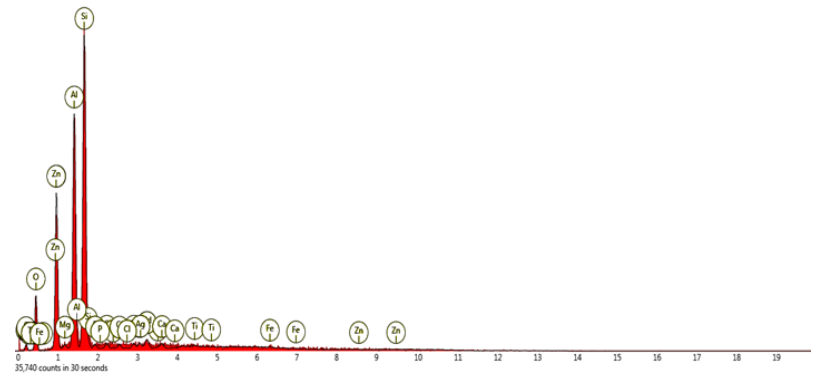

(c)

Fig. 5. SEM/EDS of the synthesized zeolite $\mathrm{NaA}$ at $3.0 \mathrm{M} \mathrm{NaOH}$ from (a) $\mathrm{IK}_{\text {clay }}$ (b) $\mathrm{OK}_{\text {clay }}(\mathrm{c}) \mathrm{KA}_{\text {clay }}$

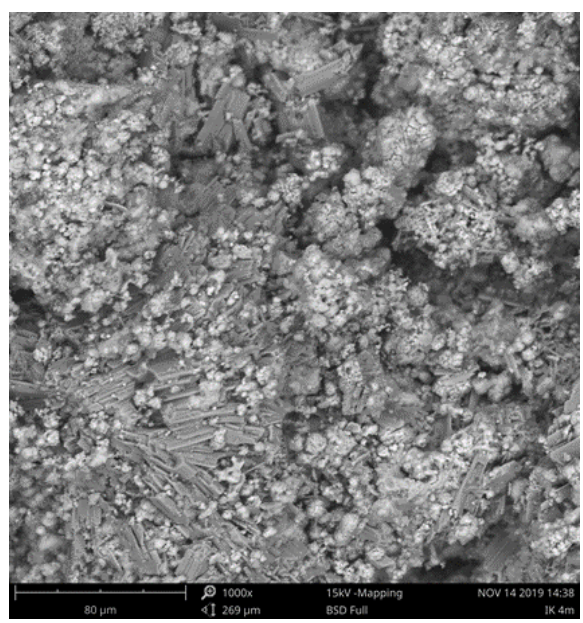




\begin{tabular}{|l|l|r|r|}
\hline Element Symbol & Element Name & Atomic Conc. & Weight Conc. \\
\hline $\mathrm{Si}$ & Silicon & 22.13 & 29.09 \\
\hline $\mathrm{O}$ & Oxygen & 30.02 & 22.48 \\
\hline $\mathrm{Al}$ & Aluminum & 14.29 & 18.05 \\
\hline $\mathrm{Na}$ & Sodium & 13.52 & 14.54 \\
\hline $\mathrm{P}$ & Phosphorus & 0.35 & 0.51 \\
\hline $\mathrm{Cl}$ & Chlorine & 0.27 & 0.45 \\
\hline $\mathrm{Ca}$ & Calcium & 0.20 & 0.37 \\
\hline $\mathrm{K}$ & Potassium & 0.00 & 0.00 \\
\hline
\end{tabular}

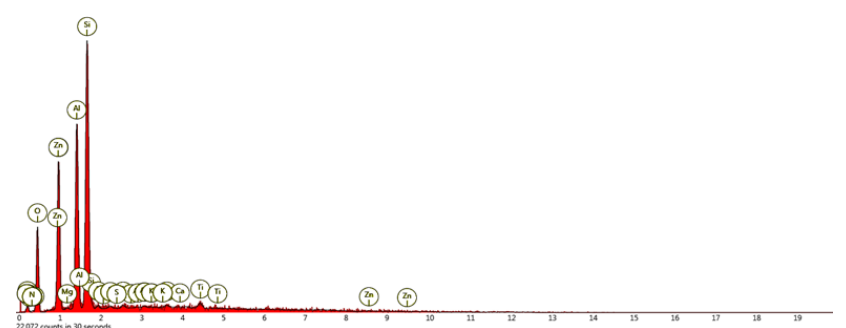

(a)

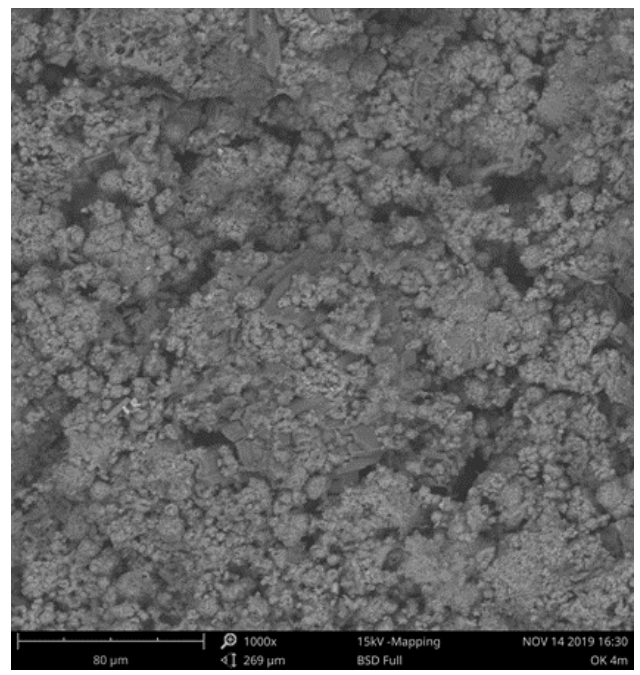

\begin{tabular}{|l|l|r|r|}
\hline Element Symbol & Element Name & Atomic Conc. & Weight Conc. \\
\hline $\mathrm{Si}$ & Silicon & 18.79 & 24.72 \\
\hline $\mathrm{O}$ & Oxygen & 32.23 & 24.15 \\
\hline $\mathrm{Al}$ & Aluminum & 14.15 & 17.89 \\
\hline $\mathrm{Na}$ & Sodium & 12.61 & 13.57 \\
\hline $\mathrm{K}$ & Potassium & 0.46 & 0.84 \\
\hline $\mathrm{Cl}$ & Chlorine & 0.48 & 0.79 \\
\hline $\mathrm{P}$ & Phosphorus & 0.42 & 0.60 \\
\hline $\mathrm{Fe}$ & Iron & 0.23 & 0.60 \\
\hline $\mathrm{Zn}$ & Zinc & 0.00 & 0.00 \\
\hline
\end{tabular}

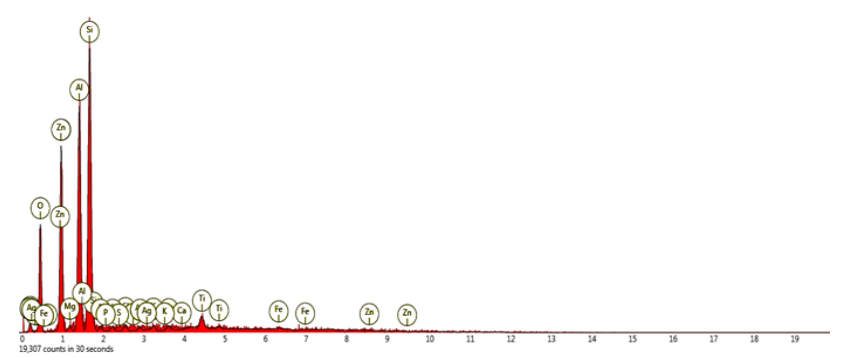

(b)

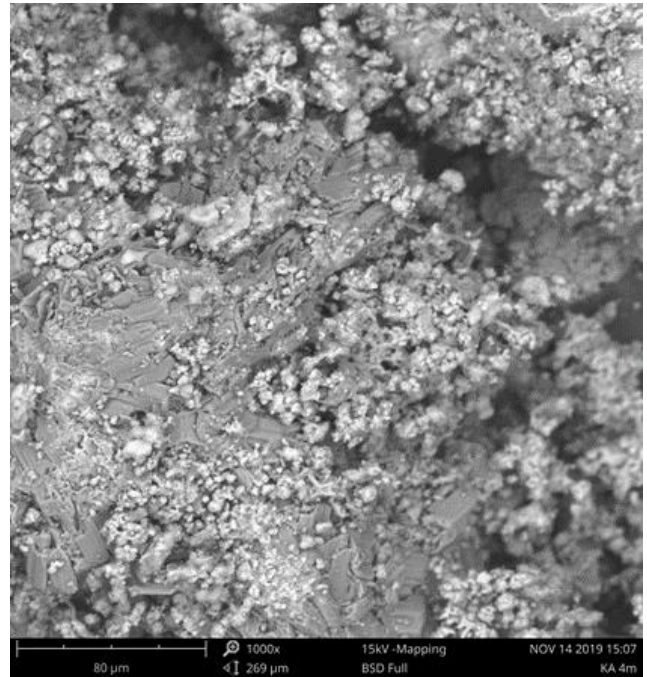

\begin{tabular}{|l|l|l|l|}
\hline Element Symbol & Element Name & Atomic Conc. & Weight Conc. \\
\hline $\mathrm{Si}$ & Silicon & 27.50 & 31.65 \\
\hline $\mathrm{Al}$ & Aluminum & 19.00 & 21.00 \\
\hline $\mathrm{O}$ & Oxygen & 31.66 & 20.76 \\
\hline $\mathrm{Na}$ & Sodium & 16.25 & 15.31 \\
\hline $\mathrm{K}$ & Potassium & 0.71 & 1.13 \\
\hline $\mathrm{P}$ & Phosphorus & 0.64 & 0.81 \\
\hline $\mathrm{Cl}$ & Chlorine & 0.48 & 0.70 \\
\hline $\mathrm{Zn}$ & Zinc & 0.00 & 0.00 \\
\hline
\end{tabular}

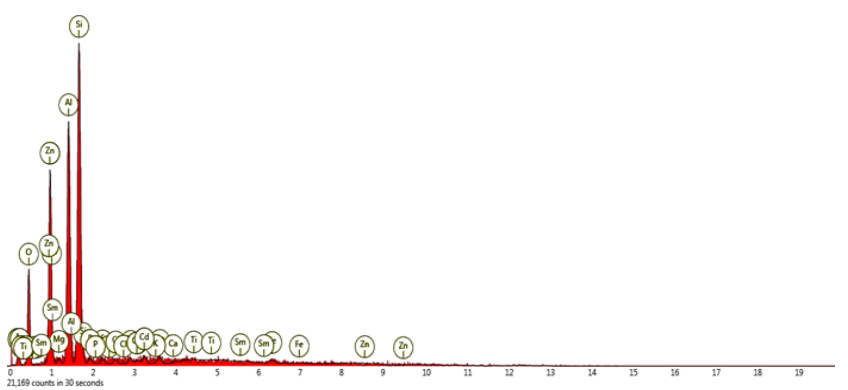

(c)

Fig. 6. SEM/EDS of the synthesized zeolite $\mathrm{NaA}$ at $4.0 \mathrm{M} \mathrm{NaOH}$ from (a) $\mathrm{IK}_{\text {clay }}$ (b) $\mathrm{OK}_{\text {clay }}(\mathrm{c}) \mathrm{KA}_{\text {clay }}$

\section{2) FT-IR analysis}

Figures $7(a-c)$ illustrate the representative IR spectra of the synthesized zeolite products at $\mathrm{NaOH}$ concentrations of 3.0 and 4.0 $\mathrm{M}$ respectively. The IR spectra were recorded a wavenumber $4000-500 \mathrm{~cm}^{-1}$. Representative diagrams are used because all the samples showed similar IR pattern and values. It is observed from the IR spectra that the band observed between $750-650 \mathrm{~cm}^{-1}$ is attributed to symmetric $\mathrm{T}-\mathrm{O}-\mathrm{T}$ vibration (where $\mathrm{T}=\mathrm{Si}$ or $\mathrm{Al}$ ) which is on agreement with values reported for $\mathrm{NaA}$ zeolite in previous work [25]. The broad band between $4000-3000 \mathrm{~cm}^{-1}$ might be attributed to the vibration stretching of hydroxyl group of water molecules and amines present in the pores of the zeolites [26, 27] while the band observed at $957 \mathrm{~cm}^{-1}$ is related to HS [25]. However, the band observed at $1650 \mathrm{~cm}^{-1}$ might be attributed to zeolitic water $[1$,$] while the peaks observed at 1450 \mathrm{~cm}^{-1}$ might be due to excess alumina present in the pore has also reported by Byrappa and Suresh Kumar [26]. The initial weak peak observed at about $550 \mathrm{~cm}^{-1}$ can be attributed to external linkages, is characteristics 
of zeolite NaA [25]. The IR peak also observed at about 850 $\mathrm{cm}^{-1}$ is also characteristic of zeolite $\mathrm{NaA}$ as reported by Markovic et al. [28].

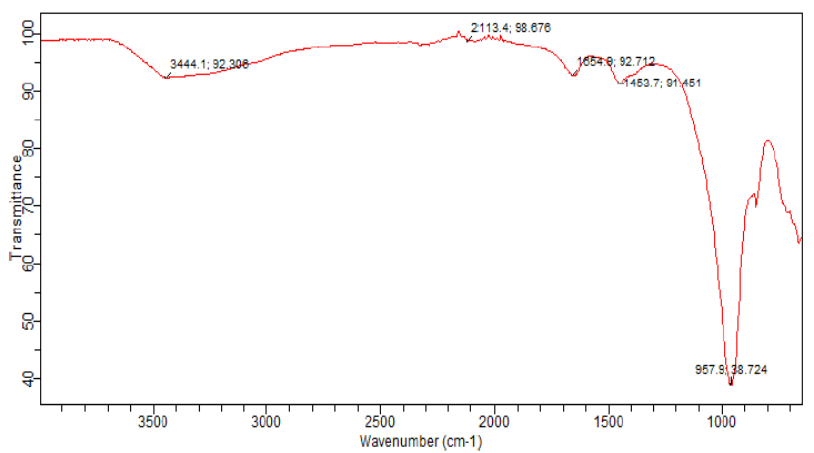

(a)

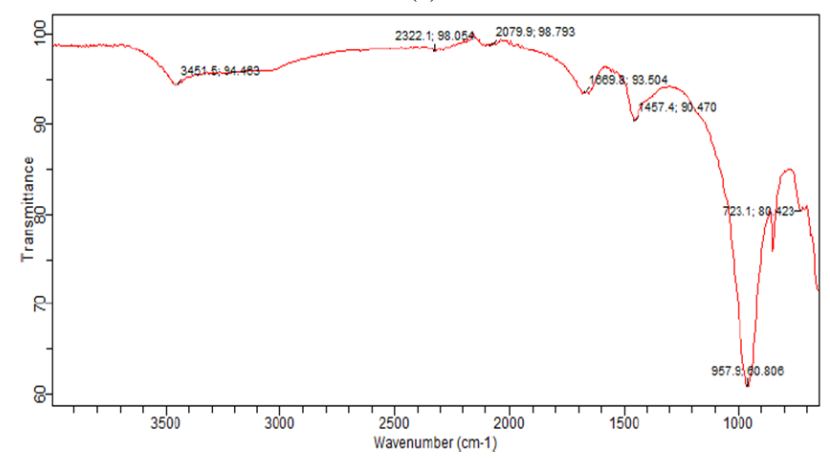

(b)

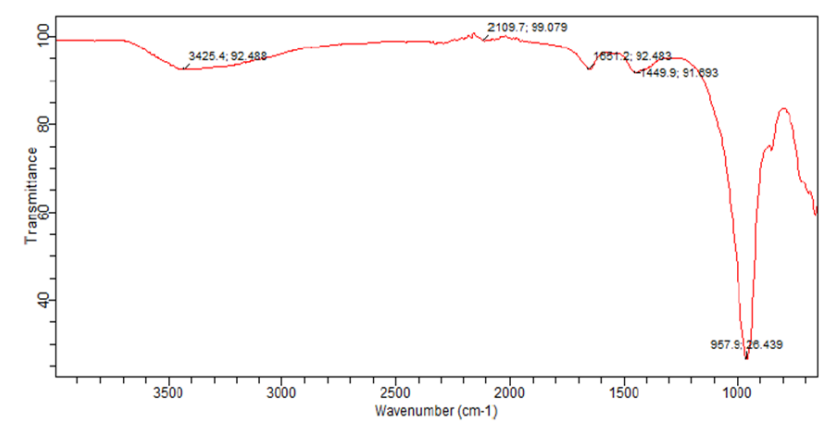

(c)

Fig. 7. IR spectra of synthesized zeolite $\mathrm{NaA}$ from (a) $\mathrm{IK}_{\text {clay }}$ (b) $\mathrm{OK}_{\text {clay }}$ (c) $\mathrm{KA}_{\text {clay }}$

\section{Conclusion}

In this work, investigations have been successfully carried out on the synthesis and characterization of Zeolite NaA using natural kaolinite clays from Nigeria by low temperature hydrothermal method. The following conclusions were drawn based on the results of SEM/EDS and IR of the produced zeolite $\mathrm{NaA}$ by reacting activated metakaolins obtained from respective kaolinite clays with various concentrations of $\mathrm{NaOH}$ solution at $100^{\circ} \mathrm{C}$ :

- Kaolinite clays obtained from Nigeria are suitable raw materials for precursors in the hydrothermal synthesis of zeolite NaA thus justifying their feasibility and economical for the industrial production of Zeolite $\mathrm{NaA}$ instead of using chemical grade materials.

- The morphology evaluation showed the presence of hydroxysodalite (HS) growing on the surface of the zeolite $\mathrm{NaA}$ matrix while the chemical composition revealed by the EDS spectra indicate major elements such as $\mathrm{Si}, \mathrm{Al}, \mathrm{O}, \mathrm{Na}$ confirming the synthesized products are zeolite $\mathrm{NaA}$ while the presence of $\mathrm{Cl}$ confirms HS phase.

- The sodalite content increased with the increase in $\mathrm{NaOH}$ concentration resulting into increased HS phase identified by spheroidal cotton-ball like morphology which could account for reduction in Zeolite NaA phase thus affecting the conspicuousness of the cubic crystal morphology known with NaA zeolite.

- In order to prevent the occurrence or prevalence of HS phase in Zeolite $\mathrm{NaA}$ matrix, $\mathrm{NaOH}$ concentrations must not be high.

- The results of the IR spectra showed that the peaks and wavenumber obtained are characteristics of Zeolite $\mathrm{NaA}$ as also supported by previous works.

- For future work, the efficiency of the synthesized zeolite products as cation exchangers and adsorbents shall be evaluated.

\section{Acknowledgement}

The authors acknowledged the effort of TETfund Nigeria and Centre for Research, Innovation and Development of the Federal Polytechnic, Ado-Ekiti, Nigeria for the research grant given to finance this work.

\section{References}

[1] G. Mousa, J.- Ch. Buhl, Synthesis and characterization of zeolite A by hydrothermal transformation of natural Jordanian kaolin, J. of the Assoc. of Arab Univ. for Basic and Appl. Sci. 15 (2014) 35 - 42.

[2] D.W. Breck, Zeolites Molecular Sieves, Structure, Chemistry and Use. New York, John Wiley \& Sons, 4 (1974) 771-780.

[3] A.T. Chiang, K.J. Chao, Membranes and films of zeolite and zeolite like Materials, J. of Physics and Chemistry of Solids 62 (2001) 1899-1910.

[4] S.M. Abegunde, K.S. Idowu, O.M. Adejuwon, T. Adeyemi-Adejolu, A review on the influence of chemical modification on the performance of adsorbents, Resources, Environment and Sustainability, 1(2020) 100001.

[5] B.K. Marcus, W.E. Cormier, Going green with zeolites, Chemical Eng. Progress, 95(1999) 47-53.

[6] E.M. Henry, C.E. Ikenna, I.L. Ganiyu, Zeolite synthesis, characterization and application areas: A Review. Int. Res. J. Environmental Sci. 6(2017) 45-59.

[7] A.Y. Atta, O.A. Ajayi, S.S. Adefila, Synthesis of Faujasite zeolites from Kankara kaolin clay, J. App. Sci. Res. 3 (2007) 1017-1021.

[8] Georgiev, D., Bogdanov, B., Angelova, K., Markovska, I., Hristov, Y., Synthetic zeolite - structure, classification, current trends in zeolite synthesis review. Int. Sci. conf., Stara Zagora, Bulgaria, (2009) 4 - 5 .

[9] S. Chandrasekhar, P.N. Pramada, Investigation on the synthesis of zeolite NaX from Kerala Kaolin, Journal of Porous Mater. 6 (1999) 283-297.

[10] D.W. Breck, Synthetic zeolite: properties and applications, Lefond, S. J ed., Industrial Minerals and Rocks, New York, American Institute of Mining, Metallurgy and Petroleum Engineering, Inc. 3(7) (1975)12431274 .

[11] R.M. Barrer, Zeolites and clay minerals as sorbents and molecular sieves, Academic Press, London. 1978.

[12] A.Y. Atta, B.Y. Jibril, B.O. Aderemi, S.S. Adefila, Preparation of analcime from local kaolin and rice husk ash, Applied Clay Sci. 61 (2012) $8-13$.

[13] M. Alkan, C. Hopa, Z. Yilmaz, H. Güler, The effect of alkali concentration and solid/liquid ratio on the hydrothermal synthesis of zeolite NaA from natural kaolinite, Microporous and Mesoporous Mater. 86(1-3) (2005) 176-184. 
[14] H. Zhao, Y. Deng, J. Harsh, M. Flury, J. Boyle, Alteration of kaolinite to canrinite and sodalite by simulated Hanford waste and its impact on cesium retention. Calys Clay Miner. 52 (1) (2004) 1-13.

[15] J.C. Covarrubias, R. Garcia, R. Arriagada, J. Yanez, T. Garland, Cr(III) exchange on zeolites obtained from kaolin and natural mordenite, Microporous Mesoporous Mater. 88 (2006) 220-231.

[16] J. Mon, Y. Deng, M. Flury, J. Harsh, Cesium incorporation and diffusion in cancrinite, sodalite, zeolite, and allophane, Microporous Mesoporous Mater. 86 (2005) 277-286.

[17] V. Sanhueza, U. Kelm, R. Cid, Synthesis of molecular sieves from Chilean kaolins: Synthesis of NaA type zeolite, J. Chem. Technol. Biotechnol. 74 (1999) 358-363.

[18] L.M. Marcelo, I.P. Diego, R.C. Nadia, Fernandes.Machado, Sibele, B.C. Pergher, Synthesis of mordenite using kaolin as Si and Al source, Appl. Clay Sci. 41 (2007) 99-104.

[19] J.B. Adeoye, J.A. Omoleye, M.E. Ojewumi, R. Babalola, Synthesis of zeolite Y from kaolin using novel method of dealumination, Inter. J. of Appl. Eng. Res. 12 (5) (2017) 755-760.

[20] A.R. Carlos, D.W. Craig, M.C. Oscar, Crystallization of low silica Na-A and $\mathrm{Na}-\mathrm{X}$ zeolites from transformation of kaolin and obsidian by alkaline fusion, Ingeniería y Competitividad 14 (2) (2012) 125 - 137.
[21] N.J. Saikia, D.J. Bharali, P. Sengupta, D. Bordoloi, R.L. Goswamee, P.C. Saikia, P.C. Borthakur, Characterization, beneficiation and utilization of a kaolinite clay from Assam, India, Appl. Clay Sci. 24 (2003) 93- 103.

[22] L. Vaculíková, E. Plevová, S. Vallová, I. Koutník, Characterization and differentiation of kaolinites from selected Czech deposits using infrared spectroscopy and differential thermal analysis, Acta Geodyn. Geomater. 8 (161) (2011) 59-67.

[23] D. Makia, E. Georges, O. Jason, Fourier transform infrared spectroscopy and thermal analyses of kaolinitic clays from South Africa and Cameroon, Acta Geodyn. Geomater. 13 (2016) 149-158.

[24] G. Zahra, Y. Habibollah, Preparation and characterization of nanozeolite $\mathrm{NaA}$ from rice husk at room temperature without organic additives, J. of Nanomaterials, 2011.

[25] E.M. Flaningen, H.A. Khatami, H.A. Szymanski, Infrared structural study of zeolite frameworks, Molecular Sieve Zeolites 16 (1971) $201-229$.

[26] K. Byrappa, B.V. Suresh Kumar, Characterization of zeolites by infrared spectroscopy, Asian J. of Chem. 19 (6) (2007) 4933 - 4935.

[27] E.F Olasehinde and S.M. Abegunde, Preparation and characterization of a new adsorbent from Raphia taedigera seed, Res. Eng. Struct. Mater., 2020; 6(2): 167-182.

[28] S. Markovic, V. Dondur, R. Dimitrijevic, FTIR spectroscopy of framework aluminosilicate structures: carnegietie and pure sodium nepheline, J. of Molecular Structure 654 (1) (2003) 223 - 234. 